participation of the state, business, science, civil society structures on the basis of mutual responsibility and the introduction of civil legal bases in relations between the state and nature users. It is necessary to develop forms of public-private partnership, ensure transparency of property relations, stimulate the private sector to efficient use of natural resources, environmentally responsible behavior and preservation of the environment.

Arctic projects require significant costs and calculation of long-term results. Therefore, strategic planning is becoming especially important for the Arctic, not tied to the short-term conjuncture of economic cycles. It is necessary to give serious attention to the exploration of reserves, create a reliable infrastructure for ensuring economic activity using the mechanisms of public-private partnership.

The increasing dependence of the world economy on energy resources is pushing the country to actively develop new strategies to promote its interests. The role of public-private partnership in this regard can not be overestimated. Overcoming the heterogeneity of the economic space of the Arctic region is possible through the implementation of mega-projects with the participation of the state and business at various levels. The most important condition for successful interaction between state and private structures is harmonization of conflicting interests in the development of Arctic deposits.

Thus, the wide use of public-private partnership mechanisms in the Arctic zone of Russian Federation will ensure sustainable development of the region in the long term, as well as contributing to the development of the country's economy.

1. Federal Law No. 224-FZ of July 13, 2015 (as amended on July 3, 2016) "On Public-Private Partnership, Municipal-Private Partnership in the Russian Federation and Amendments to Certain Legislative Acts of the Russian Federation" (amended and supplemented ., effective from 01/01/2017) .- 2015.

2. Strategy for the development of the Arctic zone of the Russian Federation and ensuring national security for the period until 2020 [Electronic resource] .- 2013.- Access mode: http://www.government.ru/docs/22846.

3. Cherepovitsyn A.E. Social and economic potential of large-scale oil and gas offshore development projects: risks and expectations of stakeholders / Notes of the Mining Institute T.215. - SPb., 2015.

4. Valinsky, Interview with the head of Norilsk O.G. The Kuril Islands need well-thought-out solutions / A.Valinsky // The Parliamentary Newspaper. - 06/14/2016. - Access mode: http://www.ras.ru/news/shownews.aspx?id=bde1f7fb-42ed-4990-bbf1-9a3fccf73053\&print=1.

5. Dudin M.N. National priorities in the sphere of institutional and innovative subsoil use of the Arctic territories / National interests: priorities and security 8 (293) .-- 2015.

6. Pytkin AN, Balandin DA The main investment risks of subsoil use in the Arctic region / Russian Entrepreneurship No. 6 (228). - March 2013

7. Aseev AL, Afanasyev VP, Bogoyavlensky VI and others. A special report to the International Forum of Technological Development "Technoprom-2016". - Novosibirsk 2016.

\title{
Kirizleyeva A.S. \\ The problems of adequacy of banking institutions establishment and development in Russia and Ukraine: comparative aspect
}

doi 10.18411/scc-30-09-2017-06

SEIHPE «DonAUiGS»

(Ukraine, Donetsk)

idsp 000001:scc-30-09-2017-06

\section{Abstract}

Successful promotion of the countries in the hierarchy of economic development has divided all the countries into the clubs - developed, developing and third world, which illustrates the irregularity of the countries' development. This trend of irregular development affect, naturally, the state of all the components of the financial market, including the state and functioning of banking institutions of different countries. 
The author analyses the functioning of banking institutions in Russia and Ukraine, as the level of their development influences the production, investment, financial and social processes of the state.

Keywords: bankinginstitutions, financial markets, asset and liability management

\section{Аннотация}

Успешное продвижение государств в иерархии экономического развития привело к делению стран мира на клубы - развитые, развивающиеся и третий мир, что по существу иллюстрирует неравномерность развития стран. Эта тенденция неравномерного развития влияет, естественно, и на состояние всех составляющих финансового рынка, в том числе на состояние и функционирование банковских институтов разных стран.

Автором проводится анализ и исследование проблем функционирования банковских институтов в России и Украине, поскольку степень их развития влияет на обеспечении производственных, инвестиционных, финансовых и социальных процессов страны.

Ключевые слова: банковские институты, финансовые рынки, управление пассивами и активами банка

In the conditions of the development of processes of the world financial system globalization the developed and developing countries set the strategic tasks of the modernization of financial institutes and instruments of the financial market - credit, currency, securities etc. The economies of the developed countries are competitive and provide their economic independence. The developed financial markets provide more liquidity for the market participants than small markets with a small number of participants and financial instruments and, thus, limited trading opportunities.

Because of the exacerbation of the crisis in the world economy the number of countries that cannot ensure the fully developed financial markets is rising. This crisis has led to the number of regulatory changes on the international banking sector. The ongoing changes and their speed are one of the most significant reforms in the current baking history.

Non-organized financial market of the country, unstable banking sector cannot qualitatively raise the liquidity of banking institutions, create the conditions for the development of financial products of commercial banks.

In Russia and Ukraine, the countries with developing economies, in the situation of economic crisis and instability of the banking system, there is the deposit outflow, at that the credits are made much more: the policy of the banking business is counterproductive, the asset and liabilities management is inefficient, which lead to banks losing their reliability. Today in such banks the service of their clients is discontinued and the accounts are frozen. This paralyses the work of these banks until the central bank of the state makes the final decision to discontinue the activity of the bank of the financial market or to adopt the recovery scheme. The bank's clients cannot receive their assets during this period. On the one hand, it helps strengthen the banking system of the country. On the other hand, it creates the population distrust of the banks stability and money outflow from commercial banks, which discredits their solvency.

Analyzing the labour market in Russia and Ukraine and the number of employees in the banking system during the past decade one can notice the trend of the rising of the indices under analysis in the periods of economic stability and development, and on the contrary in 2009 - during the financial crisis - the outflow of workers. In Ukraine the stable increase of employment in the banking sector was noticed only from 2005 to 2008. In 2009-2010 the financial crisis significantly influenced the banking sector and all its indices and led to the decrease in the number of bank workers $(2008-394.9$ th. people, $2010-332.8$ th. people, 2011 - a small-scale increase -350.6 th. people). After the increase in the banking sector 
employment in 2011, which made 350.6 th.people, from 2012 to 2015 there is a dramatic and significant drop in employment in the banks of Ukraine, which made only 243.6 th.people in 2015. It can be accounted for by a dramatic closing of commercial banks in Ukraine. At that in the banking sector of Russia during the whole analysed period the increase is marked, and this index in 2015 was 72323.6 th.people.

Tables 1 and 2 present the interrelation of the balance sheet of the banking sectors of Russia and Ukraine for 2007-2016, which reflect the opportunities for the activity of banks, direction of their deposits, scale and opportunities of which depend on the volume and quality of the formed resources, reflected in the liabilities of a modern bank [1-6].

Table 1

Interrelationof the balance sheet of the banking sector of Ukraine (in \%)

\begin{tabular}{|c|c|c|c|c|c|c|c|c|c|c|}
\hline Year & 2007 & 2008 & 2009 & 2010 & 2011 & 2012 & 2013 & 2014 & 2015 & 2016 \\
\hline credits/assets & 78,4 & 80,9 & 79,8 & 75,2 & 73,1 & 66 & 66,3 & 69,6 & 64,22 & 59,4 \\
\hline $\begin{array}{c}\text { deposits/asse } \\
\text { ts }\end{array}$ & 53,2 & 46,9 & 46,5 & 50,3 & 53,2 & 56,5 & 58,6 & 56,6 & 62,2 & 69,1 \\
\hline $\begin{array}{c}\text { securities/ } \\
\text { assets }\end{array}$ & 3,8 & 3,7 & 4 & 8,4 & 7,9 & 8,1 & 10,4 & 12,4 & 15,7 & 26,1 \\
\hline $\begin{array}{c}\text { credits/depos } \\
\text { its }\end{array}$ & 147,2 & 172,3 & 171,3 & 149,3 & 137,5 & 116,8 & 113,2 & 122,9 & 103,1 & 85,9 \\
\hline
\end{tabular}

The biggest percentage in banks' liabilities is presented by the attracted funds of the bank's clients to the current and deposit accounts $(50 \%-70 \%)$.

At that it should be mentioned that there is a stable trend to form the bank recourse base mostly at the expense of attraction of idle funds of private individuals. Thus, forexample, inUkrainein 2007 - 163482 mlnUAH, 2014 - 416 371mlnUAH,andin2016- 437152 mlnUAH,outofwhichperiodfunds, i.e. moneyondepositaccounts, makeupthemajor share of funds compared with the funds on current accounts (both in 2007 and $2014-77 \%$ ): in2007 125625 mln UAH, in 2014 - 319121 mln UAH, i.e. almost three times more. The funds of business entities attracted to current and deposit accounts of banks grew 3.3 times from 2007 to 2016. While the funds of clients-private individuals are mostly on deposits, legal entities have the funds almost evenly divided between saving them on deposit accounts to get income and having the funds on current accounts to conduct their business activity, which is only natural.

In Russia even during the years of economic crisis the balance sheet total increased. The major part of the banks liabilities is clients' funds: $56 \%$ in $2007,57 \%$ in 2016 , at that the absolute difference between these years made 37751100 mlnrub., almost in 4.08 times.

Table 2

Interrelationof the balance sheet of the banking sector of Russia (in \%)

\begin{tabular}{|c|c|c|c|c|c|c|c|c|c|c|}
\hline Year & 2007 & 2008 & 2009 & 2010 & 2011 & 2012 & 2013 & 2014 & 2015 & 2016 \\
\hline credits/assets & 71 & 71,2 & 67,5 & 65,6 & 69 & 68,7 & 70,6 & 67,1 & 69,3 & 69,5 \\
\hline deposits/assets & 60,9 & 52,6 & 58,2 & 62,4 & 62,7 & 60,8 & 60,8 & 56,4 & 62,5 & 62,5 \\
\hline $\begin{array}{c}\text { securities/ } \\
\text { assets }\end{array}$ & 11,2 & 8,4 & 14,6 & 17,2 & 14,9 & 14,2 & 13,6 & 12,5 & 14,2 & 14,3 \\
\hline credits/deposits & 116,6 & 135,2 & 116 & 105,2 & 110,2 & 112,9 & 116 & 118,9 & 110,8 & 11,2 \\
\hline
\end{tabular}

The capital base of banks is the capital of the bank and traditionally made $12 \%$ in 2007 and 2016, which is mostly made of authorized capital stock. It is necessary to notice that there is a negative trend of decrease of the capital base due to losses in the banks' activity in Ukraine during 2009-2011 and in 2014-2016 this result became much worse, which has continued since then. The losses of Ukrainian banks made $81933 \mathrm{mln} r u b$ in 2009, in $2010-$ 27758 mlnrub, 2011 - 16424 mlnrub,in 2014- 172372 mlnrub, 2015 - 154593 mlnrub, in 2016 - 341248 mlnrub. 
The analysis of the dynamics and structure of the asset of commercial banks of Russia and Ukraine during 2007 - 2016 shows the formation of nondiversifiable asset portfolio and significantly increases the risks of banking activity [1 - 6].

Practically all capital base, attracted funds and deposits by customers are allocated for crediting corporate customers and less private individuals. In Ukraine crediting corporate customers made $276184 \mathrm{mln}$ UAH in 2007, private individuals - $153633 \mathrm{mln}$ UAH, and in 2014 it was $802582 \mathrm{mln}$ UAH and179 040mln UAH correspondingly. In Russia the volumes of crediting business entities and population doubled: in 2008 - 6299671.54 mlnrub., 2014 $17871525.25 \mathrm{mln}$ rub. Creditingofcorporatecustomerswas6 $171612 \mathrm{mln}$ rub in 2009, private individuals - 1028 313.7mlnrub., and in 2014 it was $13024689.2 \mathrm{mln}$ rub. and $433722.1 \mathrm{mln}$ rub.correspondingly. In all countries commercial banksdirect their funds to credit corporate customers - major enterprises, which minimizes the banking risk, ensures more stable longterm profit and a more probable return of the crediting resources.

InRussiaandUkrainethebanksdirecttheircapitalbaseonloansforvarioustypesofactivities: 'wholesaleandretailtrade, repairofautomobiles, motorcycles, personal appliances' (in Ukraine in 2009 this index was $35.10 \%$ and in 2016 - 33.73\%, in Russia it was 24.61 and $22.20 \%$ correspondingly).

During the analyzed period the banks of Russia and Ukraine financed 'agriculture, hunting and forestry' within the limits of 7-8\%. Not significant resources were sent to finance mining industry, building, gas, water and service sector.

The banks of Russia and Ukraine lack thelong-term stable resources to finance longterm profitable projects. Therefore, the banks mostly provide short-term credits.

It should be noted that at the asset and loan portfolio increase during 2005-2016, the quality of the loan portfolio is decreasing: the share of non-performing loans is twicemore, the level of non-performing loans in Russia is not decreasing (tables 3, 4).

From 2005 to 2009 the non-performing loans were at different levels, but made up significant share - 15-23\% - of the loan portfolio. In 2005 the index was much higher $60 \%$, as the banks provided loans during the crisis when they had to limit crediting. The same trend can be seen nowadays, therefore in 2016 the share of non-performing loans made $53 \%$ and in $2015-48 \%$ of the loan portfolio.

Table 3

Dynamics of non-performing loans indices in Ukraine (in \%)

\begin{tabular}{|c|c|c|c|c|c|c|c|c|}
\hline Year & 2009 & 2010 & 2011 & 2012 & 2013 & 2014 & 2015 & 2016 \\
\hline $\begin{array}{c}\text { Shareofnon- } \\
\text { performingloansinthegeneralloansvolume }\end{array}$ & 13,7 & 15,27 & 14,73 & 16,54 & 12,89 & 18,98 & 28,03 & 30,47 \\
\hline Rate of growth of provided loans & $-6,20$ & 0,96 & 8,85 & $-3,47$ & 13,88 & 8,09 & $-11,19$ & $-6,96$ \\
\hline Rate of growth of non-performing loans & 244,54 & 14,09 & 4,91 & 34,03 & $-9,63$ & 63,10 & 45,76 & 10,25 \\
\hline
\end{tabular}

The analysis also shows that in Russia and Ukraine commercial banks provide credits faster than they form more stable resources base in the form of deposits, and in the banks of the developed countries credit operations are proportional to attraction of the clients' time deposits.

Table 4

Dynamics of non-performing loans indices in Russia (in \%)

\begin{tabular}{|c|c|c|c|c|c|c|c|c|}
\hline Год & 2009 & 2010 & 2011 & 2012 & 2013 & 2014 & 2015 & 2016 \\
\hline $\begin{array}{c}\text { Доля проблемных кредитов в общем } \\
\text { объеме кредитов }\end{array}$ & 9,5 & 8,2 & 6,6 & 6 & 6 & 6,7 & 8,3 & 9,4 \\
\hline $\begin{array}{c}\text { Темп роста объема выданных } \\
\text { кредитов }\end{array}$ & $-0,31$ & 11,51 & 29,64 & 18,29 & 19,25 & 28,57 & 10,35 & $-3,29$ \\
\hline Темп роста проблемных кредитов & 136,44 & 6,12 & 12,18 & 12,95 & 12,03 & 37,2 & 47 & 2,48 \\
\hline
\end{tabular}

Banking institutions increase assets to receive the highest profit. This profit covers banking risks. 
But in Ukraine there is an opposite, negative situation. Despite the fact that in all years, except 2009, the banks increase assets, i.e. active bank operations grow to receive profit, the banks show losses in their financial accounts and their result for the state budget is negative for many years (for example, 2009 - $81933 \mathrm{mln}$ rub, 2014 - $172372 \mathrm{mln}$ rub, 2016 - $341248 \mathrm{mln}$ rub) or insignificant on income tax assessment (for example, 2011 - 1211.97 mln UAH, 2012 - 379.31 mln UAH, 2013 - 1629.73 mln UAH).

We should complete the above analysis by the data on the profit of banks of Russia during the past 12 years: in 2005 it made $262100 \mathrm{mln}$ rub., in $2006-371$ 500, 2007 - 508 000, 2008 - 409 200, 2009 - 205 100, 2010 - 573 400, 2011 - 848 200, 2012 - 1011900 , 2013 - 993600,2014 - 589100,2015 - 192000,2016 - 929 700mln rub. Wecannoticeapositivetrend: thebanksofRussiacontribute significantly to the economy of the country, showing yearly the financial result - profit in banks' balance sheets and remitting profit tax. There was no loss in any balance sheets, except the fact that in 2010 due to economic crisis the banks showed less profit.

Existing today in many countries with the developing economy the problem of limited information and absence of financial transparency means that the information is not available for the market members, therefore the risks can be higher than in the countries with the developed financial systems. Moreover, it is more difficult to form the diversified assets portfolio of the banks on a small market with the limited choice of financial assets, savings and investment products. On the financial market with a not significant trading activity and alternatives it can be more difficult and expensive to find the right product and risk portfolio to meet the demands of the credit users and credit providers, investors and emitters.

During the research there were marked out problems of the development of banking activity in the countries with the developing economies, particularly with the reduction of demand and supply of financial services, low level of assets portfolio diversification, and limited use of various sources of formation of long-term, stable and cheap resources. Other problems were with insignificant contribution of the banking institutions in the formation of the revenue of the country; not justified, aggressive policy of management of asset and liability of the banks worsened the quality of the credit portfolio due to non-acquittance of credit users debts and final financial result - significant losses and loss of reliability for most banks.

Thus, to conduct efficient policy of strengthening of the banking system it is necessary to both carry out serious changes in legislative base and pursue the moves towards the formation by the banks of balanced and efficient policy of managing assets and liabilities, providing transparent and truthful information about real results of their activity, about efficient control of the use of optimization schemes of reflecting the results of the banks' activity.

1. ReviewofthebankingsectoroftheRussianFederation http://www.cbr.ru/analytics/bank_system/obs_ex.pdf

2. ReviewofthebankingsectoroftheRussianFederation http://www.cbr.ru/analytics/bank_system/obs_ex.pdf

2014. -Available at:

2015.-Available

at:

3. National bank of Ukraine. Consolidated financial statements for the year that finished December, $31,2014$. -Available at: http://www.bank.gov.ua/doccatalog/document?id=16817988

4. ReviewofthebankingsectoroftheRussianFederation. Analyticalindices. -Available at: http://kurscbr.ru/analytics/bank_system/obs_1307.pdf

5. ReviewofthebankingsectoroftheRussianFederation. http://www.cbr.ru/analytics/bank_system/obs_ex.pdf

6. Financial statements of

Analyticalindices. -Available at: http://www.bank.gov.ua/control/uk/publish/category?cat_id=12063884 